Enlighten: Jurnal Bimbingan Konseling Islam

Volume 1 No 1 (Januari-Juni 2018) Hlm: 1-20

Tersedia online di http://journal.iainlangsa.ac.id/index.php/enlighten

ISSN 2622-8912

\title{
KINERJA GURU BIMBINGAN DAN KONSELING SERTA PEMBINAANNYA
}

\author{
${ }^{1}$ Sisca Meidina Saputri, ${ }^{2}$ Prayitno, ${ }^{3}$ Yahya Jaya \\ ${ }^{1}$ SMP N 43 Merangin Propinsi Jambi \\ ${ }^{2}$ Universitas Negeri Padang \\ ${ }^{3}$ Universitas Islam Negeri Imam Bonjol Padang \\ E-mail: cacaaryasisca@gmail.com
}

\begin{abstract}
Abstrak
Penelitian ini dilakukan karena pelaksanaan layanan bimbingan dan konseling di sekolah tidak berjalan dengan baik terutama dalam pembinaan guru bimbingan dan konseling. Ada tiga tujuan dari penelitian ini. Yang pertama adalah menggambarkan upaya pembinaan kinerja yang dilakukan oleh guru itu sendiri. Yang kedua adalah untuk menggambarkan upaya pembinaan kinerja yang dilakukan oleh kepala sekolah. Yang ketiga adalah untuk menggambarkan upaya pembinaan kinerja yang dilakukan oleh pengawas bimbingan dan konseling. Upaya pembinaan kinerja yang dibahas dalam penelitian ini terkait dengan pelaksanaan layanan bimbingan dan konseling di sekolah serta fasilitas dan dana pendukungnya. Jenis penelitian ini adalah kuantitatif dengan menggunakan metode deskriptif. Sampel penelitian ini adalah lima puluh lima guru bimbingan dan konseling dan dua supervisor dari SMP dan SMA yang dipilih dengan menggunakan teknik total sampling. Instrumen yang digunakan adalah skala model Likert. Temuan penelitian ini antara lain. Pertama, upaya yang dilakukan oleh guru bimbingan dan konseling secara rata-rata masih "kurang". Kedua, upaya yang dilakukan oleh kepala sekolah secara rata-rata masih "sangat kurang". Ketiga, upaya yang dilakukan oleh pengawas secara rata-rata masih "sangat kurang". Namun, upaya pembinaan perlu ditingkatkan dan dikembangkan baik untuk proses maupun implementasinya. Hasil penelitian ini dapat digunakan sebagai pertimbangan dalam pembinaan kinerja guru bimbingan dan konseling dalam melaksanakan layanan bimbingan dan konseling yang sukses di sekolah.
\end{abstract}

\begin{abstract}
This research is done since the implementation of guidance and counseling service at schools does not work well especially in the coaching of the guidance and counseling teachers. There are three purposes of this research. The first is to describe the perfomance coaching efforts done by the teachers themselves. The second is to describe the performance coaching efforts done by the head masters. The third is to describe the performance coaching efforts done by the guidance and counseling supervisors. The performance coaching efforts discussed in this research is related toward the implementation of the guidance and counseling service at schools as well as its supporting facilities and funds. The type of the research was quantitative by using the descriptive method. The samples were fifty five guidance and counseling teachers and two supervisors from junior and senior high schools who were selected by using the total sampling technique. The instrument used was the Likert model scale. There are three findings of the research. First, the efforts done by the guidance and counseling teachers were in the "less". Second, the efforts done by the head master were in the "very less". Third, the efforts done by the supervisors were in the "very less". However, the coaching efforts need to be improved and developed for both the process and implementation. The result of this research can be used as a consideration to the coaching of guidance and counseling teachers' performances in implementing the successful guidance and counseling services at schools.
\end{abstract}

Keywords: The performance of the guidance and counselor teachers, head masters, supervisors 


\section{PENDAHULUAN}

Undang-Undang Republik Indonesia Nomor 20 Tahun 2003 tentang Sistem Pendidikan Nasional Pasal 1 Ayat 6 menyatakan bahwa Guru BK adalah pendidik. Sebagai pendidik, maka pekerjaan utama sehari-hari Guru BK adalah melakukan upaya pendidikan dalam bentuk pembelajaran, artinya pembelajaran adalah proses interaksi, siswa dengan pendidik dan sumber belajar pada suatu lingkungan belajar.

Keberhasilan Guru BK dalam melaksanakan tugasnya sebagai pendidik dilihat dari beberapa hal, yaitu: (1) menjalankan tugas pokok serta fungsinya terhadap proses pelaksanaan pelayanan BK di sekolah, (2) adanya kegiatan tatap muka di dalam kelas selama 2 jam pembelajaran perminggu setiap kelasnya, untuk melakukan pembelajaran dalam bidang pelayanan BK di sekolah, (3) adanya siswa asuh dengan rasio satu Guru BK melayani 150 orang konseli, (4) adanya sarana, prasarana dan pembiayaan dalam menunjang pelaksanaan pelayanan BK di sekolah (Permendikbud Nomor $81 \mathrm{~A}$ ).

Salah satunya dengan cara meningkatkan kinerja Guru BK dalam pelaksanaan pelayanan BK di sekolah melalui kompetensi profesional Guru BK. Kinerja yang dimaksud dalam hal ini adalah usaha atau suatu kegiatan yang dilakukan oleh Guru BK terhadap pelaksanaan pelayanan BK sehingga apa yang hendak dicapai dapat terlaksana dengan baik serta keberadaan Guru BK dapat dirasakan manfaatnya oleh siswa dalam memberikan solusi terbaik terhadap permasalahan yang terjadi, dengan tujuan memandirikan siswa. Untuk mewujudkan pelaksanaan pelayanana BK yang berhasil, perlu adanya upaya yaitu: (1) penguasaan dan pemahaman kompetensi yang harus dimiliki oleh Guru BK, (2) adanya pembinaan yang dilakukan oleh Kepala Sekolah dan Pengawas BK, dalam hal ini Kepala Sekolah berperan sebagai pemimpin pendidikan, administrator serta supervisor di sekolah (dalam Zukhufarisma, 2012:2).

Kepala Sekolah dan Pengawas BK selaku pembina mempunyai kewajiban membimbing, membina, dan mengawasi kinerja Guru BK dalam menyelenggarakan pelayanan BK di sekolah. Peran Kepala Sekolah dan Pengawas BK yang efektif, akan mendorong semangat Guru BK ke arah perubahan yang diinginkan. Pembinaan dan bimbingan yang dilakukan sangat berpengaruh terhadap kelangsungan dan kelancaran proses pelayanan BK di sekolah, seperti kepengawasan yang dilakukan secara berkelanjutan dan menyeluruh meliputi seluruh aspek, antara lain personil, pelaksanaan kegiatan, material dan hambatan-hambatan yang muncul dalam pelaksanaan pelayanan BK di sekolah.

Penelitian Asmaryadi (2013) di SMA N 3 Padang Sidempuan menjelaskan tentang Kinerja Guru BK dan Upaya Pembinaan yang dilakukan oleh Kepala Sekolah bahwa: (a) 
kinerja Guru BK dalam pelayanan BK masih minim dan hanya sebatas pelayanan yang bersifat insidental saja, (b) upaya pembinaan yang dilakukan oleh Kepala Sekolah dalam membantu kinerja Guru BK, masih pembinaan yang bersifat menyeluruh dan belum ada pembinaan yang khusus kepada Guru BK, (c) upaya pembinaan koordinator Guru BK dalam membantu kinerja pelayanan BK masih sangat minim, seperti pembinaan mengelola program BK dalam perencanaan, penyusunan, peng-organisasian, pelaksanaan, pengontrolan dan tindak lanjut, belum memadai, (d) faktor penghambat dan pendukung dalam pembinaan kinerja Guru BK masih banyak kekurangan fasilitas, seperti alat ungkap masalah belum ada pada SMAN 3 Padang Sidempuan. Kemudian pelayanan yang belum tercapai dan belum optimal.

Senada dengan hasil penelitian sebelumnya, hasil penelitian Sunoko (2011) yang berjudul "Pembinaan Profesional Guru (Studi Pembinaan Guru, Kepala Sekolah, Pengawas dan Dinas Pendidikan di SMP N 2 Sarolangun)" menjelaskan bahwa pelaksanaan pembinaan profesional Guru BK cenderung dilakukan secara umum, pembinaan dilakukan kurang terfokus pada proses pembelajaran. Tidak terlaksananya secara optimal pembinaan kinerja Guru BK oleh Kepala Sekolah maupun Pengawas BK adalah dikarenakan masing-masing fungsi tidak berjalan sebagaimana harusnya, dikarenakan kurangnya pemahaman dan pengetahuan yang dimiliki, serta tidak menganggap penting akan keberadaan dan peran Guru BK di sekolah dalam proses pelaksanaan pelayanan bimbingan dan konseling di sekolah.

Berdasarkan studi pendahuluan yang dilakukan peneliti di Kabupaten Merangin, didapakan informasi bahwa: (1) pelaksanaan pelayanan BK oleh Guru BK masih berkualifikasi sarjana Bimbingan dan Konseling dan belum ada yang mengambil Pendidikan Profesi Konselor (PPK), (2) masih ditemukan berbagai permasalahan mengenai kinerja Guru BK dalam melaksanakan pelayanan BK, yang belum berjalan secara optimal dan profesional di sekolah, (3) tidak adanya jam masuk kelas oleh Guru BK di sekolah, (4) Guru BK masih dianggap sebagai polisi sekolah, yang bertugas hanya mengatasi permasalahan siswa yang melanggar aturan sekolah saja, (5) belum tersedianya sarana, prasarana dan pembiayaan dalam menunjang pelaksanaan pelayanan BK, diantaranya, ruangan BK yang tidak tersedia maupun kebutuhan lain yang dianggap perlu dalam pelaksanaan pelayanan BK di sekolah yang sesuai dengan Permendikbud RI Nomor 111 Tahun 2014 tentang Bimbingan dan Konseling Pada Pendidikan Dasar dan Menengah.

Hal tersebut dipertegas oleh forum Musyawarah Guru Bimbingan dan Konseling (selanjutnya disingkat MGBK), yang menyatakan, bahwa: (1) Guru BK pada jenjang SLTP berjumlah 26 orang dan SLTA berjumlah 29 orang, dengan total keseluruhan sebanyak 55 orang Guru BK yang masih berlatar belakang pendidikan S-1 BK dan belum ada yang 
berprofesi sebagai Konselor, (2) Guru BK belum mendapatkan jam masuk kelas seperti Guru Mata Pelajaran lainnya. Selanjutnya, Kepala Dinas Pendidikan Kabupaten Merangin, saat menghadiri pertemuan MGBK pada tanggal 7 Januari 2015 di SMPN 2 Merangin menyatakan bahwa: (1) Guru BK di Kabupaten Merangin masih belum memahami tugas pokok serta fungsinya sebagai Guru BK, (2) Guru BK belum mengerti mengenai kompetensi standar yang harus mereka miliki, (3) Guru BK masih bingung melaksanakan pelayanan BK yang akan diberikan setiap minggunya kepada siswa, sehingga pelaksanaan pelayanan BK dilakukan tanpa program kerja yang jelas dan tidak berdasarkan need assessment, (4) peran Guru BK dalam melaksanakan pelayanan BK di sekolah masih dianggap seperti kegiatan pemberian hukuman kepada siswa yang bermasalah, bahkan ukuran keberhasilan Guru BK dalam proses pelaksanaan pelayanan BK di sekolah, hanya terlihat pada kegiatan yang menertibkan siswa, agar mematuhi peraturan sekolah, serta tidak mengulangi perbuatan yang telah dilakukan, sehingga keberadaan dan peran Guru BK hanya dijadikan polisi sekolah.

Tentu saja hal ini menambah daftar panjang permasalahan yang terjadi pada kinerja Guru BK dan pembinaannya, yang tidak sesuai dengan ketentuan pemerintah, berdasarkan Permendiknas Nomor 27 Tahun 2008 tentang Standar Kualifikasi Akademik dan Kompetensi Konselor (yang selanjutnya disingkat SKAKK). Kinerja Guru BK dalam hal ini, dapat dilihat dari kompetensi profesional yang dilakukan oleh Guru BK, dan tentunya tidak terlepas dari kepengawasan yang dilakukan oleh Kepala Sekolah dan Pengawas BK, serta belum terciptanya kerjasama yang baik antara Guru Mata Pelajaran, wali kelas dan orangtua yang seharusnya menjadi penting untuk dikaitkan terhadap permasalahan dan perkembangan siswa di sekolah.

Dalam rangka mengungkapkan perlunya pembinaan kinerja Guru BK, maka peneliti tertarik untuk mendalami lebih jauh dan melakukan suatu penelitian yang diformulasikan dalam judul "Kinerja Guru BK dan Pembinaannya (Studi di SLTP dan SLTA Kabupaten Merangin"). Dalam penelitian ini, Konselor tidak termasuk, karena di Kabupaten Merangin hanya terdapat Guru BK saja.

Secara umum penelitian ini bertujuan untuk mengungkapkan dan mendeskripsikan tentang kinerja Guru BK dan pembinaannya seperti: (a) kualitas kinerja pelayanan BK di sekolah, (b) pembinaan kinerja yang dilakukan oleh Kepala Sekolah kepada Guru BK terhadap pelaksanaan pelayanan BK dalam memfasilitasi sarana, prasarana dan pembiayaan, (c) pembinaan kinerja yang dilakukan oleh Pengawas BK terhadap pelaksanaan pelayanan BK di sekolah.

\section{METODE PENELITIAN}


Jenis penelitian ini menggunakan pendekatan kuantitatif dengan metode deskriptif. Adapun yang menjadi populasi dalam penelitian ini adalah (1) keseluruhan Guru BK yang berada pada jenjang SMP/MTs dan SMA/SMK/MA di Kabupaten Merangin, yang berjumlah 55 orang Guru BK dengan latar belakang pendidikan S-1 BK, dan belum ada yang berprofesi sebagai konselor, (2) Pengawas BK jenjang SMP/MTs dan SMA/SMK/MA berjumlah 2 orang.

Pengambilan sampel untuk penelitian ini adalah total sampling, dengan jumlah 55 orang. Instrumen yang digunakan pada penelitian ini berupa model skala Likert, Selain itu data penelitian ini juga di dukung oleh wawancara yang ditujukan kepada Pengawas BK, berkenaan dengan pembinaan kinerja yang dilakukan.

Berdasarkan hasil pengolahan data untuk reliabilitas, diperoleh nilai Alpha Cronbach untuk sub variabel yaitu (1) Guru BK sebesar 0,951, (2) Kepala Sekolah sebesar 0,946, (3) Pengawas BK sebesar 0,941. Dari uraian tersebut, didapatkan nilai rata-rata $r_{\text {hitung }}>r_{\text {tabel, }}$ maka ketiga instrumen penelitian dinyatakan reliabel. Adapun analisis pengolahan data dibantu dengan menggunakan program SPSS 17.

Selanjutnya, deskripsi data ketercapaian tingkat kualitas kinerja Guru BK dan pembinaan yang dilakukan oleh Kepala Sekolah serta Pengawas BK berdasarkan norma kategori. Penetapan kriteria penilaian menggunakan klasifikasi tingkat pencapaian responden menggunakan rumus mean hipotetic dengan rumus yang digunakan sebagai berikut.

$$
\text { Data Terbesar - Data Terkecil }
$$

$$
\text { Interval }_{\mathrm{k}}=
$$

$$
\text { Jumlah kelompok }
$$

Setelah didapatkan interval masing-masing variabel penelitian, kemudian dibuat pengkategorian dan persentase masing-masing variabel penelitian. Berikut uraiannya.

1) Pelaksanaan Kinerja Guru BK

Variabel kualitas kinerja Guru BK dalam pelaksanaan pelayanan BK yang dilakukan oleh Guru BK itu sendiri terdiri dari 69 item pernyataan, dengan skor tertinggi adalah 207 dan skor terendah adalah 0. Untuk mengetahui kategorisasi kualitas kinerja Guru BK, dapat dilihat pada tabel di bawah berikut ini.

Tabel 1. Kategorisasi Skor Kualitas Kinerja Guru BK dan Pembinaan yang dilakukan oleh Kepala Sekolah dan Pengawas BK

\begin{tabular}{|c|c|}
\hline Kategorisasi Kualitas \\
$\begin{array}{c}\text { Kinerja Guru BK dan } \\
\text { Pembinaannya }\end{array}$ & Rentang \\
\cline { 2 - 2 } & $\%$ \\
\hline Baik Sekali & $86-100$ \\
\hline Baik & $76-85$ \\
\hline Cukup & $60-75$ \\
\hline Kurang & $55-59$ \\
\hline
\end{tabular}




\begin{tabular}{|c|c|}
\hline Sangat Kurang & $\leq 54$ \\
\hline
\end{tabular}

2) Pembinaan Kinerja Guru BK oleh Kepala Sekolah dan Pengawas BK

Variabel pembinaan kinerja Guru BK yang dilakukan oleh Kepala Sekolah dan Pengawas BK terdiri dari 80 item pernyataan, dengan skor tertinggi adalah 240 dan skor terendah adalah 0. Untuk mengetahui kategorisasi pembinaan kinerja Guru BK yang dilakukan oleh Kepala Sekolah dan Pengawas BK, terhadap pelaksanaan pelayanan BK di sekolah, digunakan kriteria yang sama pada tabel 1 .

\section{HASIL PENELITIAN}

\section{Kualitas Kinerja Guru BK}

\section{a. Analisis data}

Berikut data rekapitulasi disribusi frekuensi kualitas kinerja Guru BK secara umum dapat dilihat dibawah ini:

Tabel 2: Distribusi Frekuensi Kualitas Kinerja Guru BK

\begin{tabular}{|c|c|c|c|}
\hline $\begin{array}{c}\text { Kelas } \\
\text { Interval } \\
\text { Skor }\end{array}$ & F & $\boldsymbol{\%}$ & Kedudukan Persentil \\
\hline $136-145$ & 1 & 2 & 2 \\
\hline $126-135$ & 5 & 9 & 11 \\
\hline $116-125$ & 20 & 36 & 47 \\
\hline $106-115$ & 23 & 42 & 89 \\
\hline $96-105$ & 4 & 7 & 96 \\
\hline $86-95$ & 1 & 2 & 98 \\
\hline $75-85$ & 1 & 2 & 100 \\
\hline
\end{tabular}

Berdasarkan tabel tersebut, dapat diketahui bahwa secara keseluruhan kualitas kinerja Guru BK pada jenjang SMP/MTs dan SMA/SMK,MA berada pada kategori kurang dengan persentase $55,09 \%$.

b. Analisis Kinerja Guru BK, Berdasarkan Item Instrumen.

Hasil pengolahan data yang diperoleh untuk mengetahui analisis kualitas kinerja Guru BK, secara keseluruhan pada jenjang SMP/MTS dan SMA/SMK/MA, menurut Guru BK, berdasarkan item instrumen dengan jumlah pernyataan sebanyak 69 item, dapat dilihat pada pada tabel 10 di bawah ini:

Tabel 3. Analisis Kinerja Guru BK, berdasarkan Skor item instrumen

\begin{tabular}{|l|c|c|c|c|}
\hline Kualitas & Rentang & Nomor Item & Jml & \% \\
\hline $\begin{array}{l}\text { Baik } \\
\text { Sekali }\end{array}$ & $86-100$ & & 0 & 0 \\
\hline Baik & $76-85$ & & & 0 \\
\hline Cukup & $60-75$ & & 0 & 0 \\
\hline
\end{tabular}




\begin{tabular}{|l|l|l|l|c|}
\hline Kurang & $55-59$ & $1,3,4,5,6,7,8,9,1$ & 46 & 67 \\
& & $2,13,14,15$ & & \\
& & $17,18,19$, & & \\
& & $20,23,28$, & & \\
& & $5,36,37,39,41,42,34,3$ & & \\
& & $, 43,45,46,47,48$, & & \\
& & $49,50,52,53,54,5$ & & \\
& & $5,56,57,61,66$, & & \\
& & 68 & & \\
Sangat & $\leq 54$ & $2,10,11$, & 23 & \\
Kurang & & $16,21,22,24,25,2$ & & \\
& & $6,27,33,38,40,44$ & & \\
& & $, 51,58,59,60,62$, & & \\
& & 63,64, & & \\
& & 65,67 & 69 & \\
\hline \multicolumn{2}{|r|}{ Jumlah } & & & \\
\hline
\end{tabular}

Hasil tabel di atas, menunjukkan bahwa setiap item aspek pelayanan BK, yang berjumlah 69 item, belum ada yang berada pada kualitas kinerja cukup, kualitas baik dan kualitas baik sekali. Namun hanya berada pada kategori kualitas sangat kurang, dengan capaian 33\%, dan pada kategori kualitas kurang, sebesar 67\%. Ini berarti bahwa kinerja Guru BK terhadap pelaksanaan pelayanan BK berkaitan dengan kompetensi profesional Guru BK, belum berjalan sebagaimana mestinya.

\section{Pembinaan Kinerja Guru BK yang dilakukan oleh Kepala Sekolah}

\section{a. Analisis Data}

Hasil data penelitian yang diperoleh dari instrumen angket tentang pembinaan kinerja Guru BK yang dilakukan oleh Kepala Sekolah menurut Guru BK, dapat dilihat pada tabel dibawah ini.

Tabel 4: Distribusi Frekuensi Pembinaan Kinerja Guru BK yang dilakukan oleh Kepala Sekolah

\begin{tabular}{|c|c|c|c|}
\hline $\begin{array}{c}\text { Kelas } \\
\text { Interval } \\
\text { Skor }\end{array}$ & $\mathbf{F}$ & $\boldsymbol{\%}$ & Kedudukan Persentil \\
\hline $141-145$ & 1 & 2 & 2 \\
\hline $136-140$ & 7 & 13 & 15 \\
\hline $131-135$ & 14 & 25 & 40 \\
\hline $126-130$ & 10 & 18 & 58 \\
\hline $121-125$ & 8 & 15 & 73 \\
\hline $116-120$ & 10 & 18 & 91 \\
\hline $110-115$ & 5 & 9 & 100 \\
\hline
\end{tabular}

\section{Keterangan:}

$$
\begin{array}{ll}
\text { N } & =55 \\
\text { Skor Ideal Per-resposnden } & =240 \\
\text { Skor Terendah } & =112 \\
\text { Skor Tertinggi } & =124 \\
\text { Jumlah Skor Keseluruhan } & \\
\text { Responden } & =6989
\end{array}
$$


Jumlah Skor Ideal seluruh

Responden $=55 \times 240=13200$

Mean $\quad=127$

Persentase Mean $\quad=52,9$

Berdasarkan tabel tersebut dapat dilihat bahwa secara keseluruhan pembinaan kinerja Guru BK yang dilakukan oleh Kepala Sekolah secara umum, pada jenjang SMP/MTs dan SMA/SMK/MA, berada pada kategori sangat kurang dengan persentase $52,9 \%$.

b. Analisis Pembinaan Kinerja Guru BK yang dilakukan oleh Kepala Sekolah menurut Guru BK, Berdasarkan Item Instrumen

Hasil pengolahan data analisis pembinaan kinerja Guru BK, yang dilakukan oleh Kepala Sekolah, berdasarkan item instrumen, pada jenjang SMP/MTs dan SMA/SMK/MA, dapat dilihat pada tabel sebagai berikut:

Tabel 5. Pembinaan Kinerja Guru BK oleh Kepala Sekolah, Berdasarkan Kualitas Item Insrumen

\begin{tabular}{|c|c|c|c|c|}
\hline Kualitas & Rentang & Nomor Item & Jml & $\%$ \\
\hline Baik Sekali & $86-100$ & & 0 & 0 \\
\hline Baik & $76-85$ & & 0 & 0 \\
\hline Cukup & $60-75$ & 55 & 1 & 1 \\
\hline Kurang & $55-59$ & $\begin{array}{l}2,3,4,7,8,10, \\
11,14,15,17, \\
18,20,21,23, \\
24,25,27,28, \\
37,38,41,47, \\
48,49,50,51, \\
52,53,54,56, \\
59,63,66,73, \\
76\end{array}$ & 35 & 44 \\
\hline Sangat Kurang & $\leq 54$ & $\begin{array}{l}1,5,6,9, \\
12,13,16,19, \\
22,26,2930,3 \\
1,32,33,34,3 \\
5,36,39,40,4 \\
2,43,44,45,4 \\
6,57,58,60,6 \\
1,62,64,65,6 \\
7,68,69,70,7 \\
1,72,74,75,7 \\
7,78,70 \\
, 80\end{array}$ & 44 & 55 \\
\hline Jun & & & 80 & 100 \\
\hline
\end{tabular}

Hasil tabel di atas, menunjukkan bahwa setiap item aspek pelayanan BK dalam hal pembinaan yang dilakukan oleh Kepala Sekolah, yang berjumlah 80 item, belum ada yang berada pada kategori baik dan kategori baik sekali. Namun hanya berada pada kategori cukup dengan capaian persentase $1 \%$, kategori sangat kurang, dengan capaian 
55\%, dan kategori kurang, sebesar 44\%. Ini berarti bahwa pembinaan kinerja Guru BK menurut Guru BK yang dilakukan oleh oleh Kepala Sekolah telah berjalan tetapi belum maksimal.

\section{Pembinaan Kinerja Guru BK yang dilakukan oleh Pengawas BK}

a. Analisis Data

Hasil data penelitian yang diperoleh dari instrumen angket tentang pembinaan kinerja Guru BK yang dilakukan oleh Pengawas BK, menurut Guru BK, dapat dilihat pada tabel sebagai berikut.

Tabel 6: Distribusi Frekuensi Pembinaan Kinerja Guru BK yang dilakukan oleh Pengawas BK

\begin{tabular}{|c|c|c|c|}
\hline $\begin{array}{c}\text { Kelas } \\
\text { Interval } \\
\text { Skor }\end{array}$ & $\mathbf{F}$ & $\%$ & $\begin{array}{c}\text { Kedudukan } \\
\text { Persentil }\end{array}$ \\
\hline $141-145$ & 1 & 2 & 2 \\
\hline $136-140$ & 2 & 4 & 6 \\
\hline $131-135$ & 10 & 18 & 24 \\
\hline $126-130$ & 17 & 30 & 54 \\
\hline $121-125$ & 6 & 11 & 65 \\
\hline $116-120$ & 11 & 20 & 85 \\
\hline $111-115$ & 6 & 11 & 96 \\
\hline $105-110$ & 2 & 4 & 100 \\
\hline
\end{tabular}

\section{Keterangan:}

$\begin{array}{ll}\text { N } & =55 \\ \text { Skor Ideal Per-resposnden } & =240 \\ \text { Skor Terendah } & =108 \\ \text { Skor Tertinggi } & =141 \\ \text { Jumlah Skor Keseluruhan } & =6847 \\ \text { Responden } & = \\ \text { Jumlah Skor Ideal seluruh } & \\ \text { Responden= 55x240 } & =13200 \\ \text { Mean } & =124 \\ \text { Persentase Mean } & =51,87\end{array}$

Berdasarkan tabel di atas dapat diketahui bahwa secara keseluruhan pembinaan kinerja Guru BK yang dilakukan oleh Pengawas BK secara umum pada jenjang SMP/MTs dan SMA/SMK/MA, berada pada kategori sangat kurang dengan persentase 51,87\%,.

b. Analisis Pembinaan Kinerja Guru BK yang dilakukan oleh Pengawas BK, menurut Guru BK, Berdasarkan Item Instrumen

Hasil pengolahan data analisis pembinaan kinerja Guru BK, yang dilakukan oleh Pengawas BK, menurut Guru BK, berdasarkan item instrumen dengan jumlah pernyataan 
sebanyak 80 item, untuk jenjang SMP/MTs dan SMA/SMK/MA. Berikut data rekapitulasi pembinaan kinerja Guru BK yang dilakukan oleh Pengawas BK, dapat dilihat pada tabel 20 sebagai berikut:

Tabel 7. Pembinaan Kinerja Guru BK oleh Pengawas BK, Berdasarkan Kualitas Item Insrumen

\begin{tabular}{|l|c|c|c|c|}
\hline Kualitas & Rentang & Nomor Item & Jml & \% \\
\hline Baik Sekali & $86-100$ & & 0 & 0 \\
\hline Baik & $76-85$ & & 0 & 0 \\
\hline Cukup & $60-75$ & & 0 & 0 \\
\hline Kurang & $55-59$ & $3,6,8,9,10,11,12,1$ & 37 & 46 \\
& & $3,14,16,1718,20,2$ & & \\
& & $1,22,23,24,25,26$, & & \\
& & $27,28,29,30,31,33$ & & \\
& & $, 34,35,37,38,39,4$ & & \\
& & $1,42,43,45,53,54$, & & \\
\hline Sangat & 554 & $63,2,4,5,7,15,19,32$ & 43 & \\
Kurang & & $, 36,40,44$, & & \\
& & $46,47,48,49,50,51$ & & \\
& & $, 52,55,56,57,58,5$ & & \\
& & $9,60,61.62$, & & \\
& & $64,65,66,67,68,69$ & & \\
& & $, 70,71,72,73,74,7$ & & \\
& & $5,76,77,78,79,80$ & & \\
& & & 80 & \\
\hline
\end{tabular}

Hasil tabel di atas, menunjukkan bahwa setiap item aspek pembinaan kinerja Guru BK yang dilakukan oleh Pengawas BK belum ada yang berada pada kategori cukup, kategori baik dan kategori baik sekali. Namun hanya berada pada kategori sangat kurang, dengan persentase 54\%, dan kategori kurang dengan persentase $46 \%$. Ini berarti pembinaan kinerja Guru BK yang dilakukan Pengawas BK belum terlaksana secara optimal dan menyeluruh, sehingga diperlukan upaya untuk meningkatkan kinerja Guru BK melalui pembinaan yang dilakukan oleh Pengawas BK agar lebih baik. 


\section{Hasil Wawancara Kepada Pengawas BK}

Hasil wawancara dengan Pengawas BK dapat dilihat pada Lampiran 7. Adapun pokok- pokoknya sebagai berikut:

a. Kegiatan kepengawasan yang dilakukan oleh Pengawas BK sudah dilakukan dan terjadwal

b. Kepengawasan yang dilakukan oleh Pengawas BK, baru sebatas pengecekan administrasi BK.

c. Pembinaan yang dilakukan oleh Pengawas BK belum secara menyeluruh sesuai dengan Guru BK binaannya.

d. Dalam melaksanakan tugasnya, Pengawas BK menyiapkan program BK, namun RKBK pengawas, belum tersusun dengan baik

e. Pengawas BK memiliki instrumen supervisi dalam bidang pelayanan BK, dan ini digunakan untuk menilai kinerja Guru BK

f. Pelaksanaan pelayanan BK di sekolah masih belum optimal dan Guru BK masih dianggap sebagai polisi sekolah

Berdasarkan data yang diperoleh bahwa kepengawasan yang dilakukan kepada Guru BK sudah dilakukan secara terjadwal. Namun masih belum dilakukan secara menyeluruh, dikarenakan lokasi sekolah yang berjauhan. Bentuk pembinaan yang dilakukan oleh Pengawas BK masih bersifat pengecekan administrasi BK, dan belum pada proses pelaksanaan pelayanan BK, serta belum semua Guru BK diberi jam masuk kelas, untuk melakukan kegiatan tatap muka di dalam kelas selama 2 jam pembelajaran perminggu setiap kelasnya.

\section{B. Pembahasan Hasil Penelitian}

\section{Kualitas Pelaksanaan Kinerja Pelayanan Guru BK di Sekolah}

Berdasarkan analisis deskripsi data yang diperoleh, menunjukkan bahwa secara keseluruhan kualitas kinerja Guru BK secara umum berada pada kualitas kurang. Hal ini terjadi karena pelaksanaan pelayanan BK belum dilakukan sebagaimana mestinya. Jika dianalisis pelaksanaan pelayanan BK per- jenjang sekolah, berdasarkan skor item instrumen menunjukkan bahwa untuk jenjang SMP/MTs berada pada kategori kualitas sangat kurang seperti belum terlaksananya pelayanan BK secara menyeluruh, sesuai dengan kompetensi profesional Guru BK, begitu juga untuk jenjang SMA/SMK/MA berada pada kategori kurang dan sangat kurang. Artinya kinerja Guru BK baik itu pada jenjang SMP/MTS dan SMA/SMK/MA, masih harus diperbaiki melalui usaha atau jenis 
kegiatan yang dilakukan Guru BK berkenaan dengan kompetensi profesional Guru BK sesuai dengan Permendiknas Nomor 27 Tahun 2008 tentang standar kualifikasi akademik kompetensi konselor.

Selanjutnya pada setiap skor kualitas pelaksanaan kinerja Guru BK, terhadap pelaksanaan pelayanan BK, dapat diartikan bahwa Guru BK belum sepenuhnya mengerti mengenai materi pendidikan terhadap objek praktik spesifik yang harus dikuasai Guru BK, dan materi dari kompetensi pelayanan BK. Ini berarti bahwa pada setiap item dari pernyataan materi pelayanan BK belum terlaksana dengan baik, dan belum sesuai dengan standar kinerja yang seharusnya dilakukan oleh Guru BK seperti knowledge, skill, and disposition, assesment, system and unit evaluations (Supardi, 2013:49). Senada dengan penelitian Metin Ozkan (2014) menjelaskan bahwa hasil studi penelitian, dari 34 program bimbingan dan psikologis konseling, terdapat 6 program bimbingan dan psikologis konseling, berada pada kategori tinggi dan sebanyak 28 program lainnya tidak memiliki kinerja yang baik atau berada pada kategori rendah. Artinya bahwa kinerja Guru BK dapat dikatakan baik, apabila pelaksanaan pelayanan BK telah dilakukan sesuai dengan aturan resmi dari pemerintah.

Bentuk pelaksanaan kinerja Guru BK sesuai dengan standar kualifikasi akademik kompetensi konselor sebagai pedoman dalam meningkatkan kualitas kinerjanya. Adapun bentuk pelaksanaan itu yaitu, usaha, tindakan serta kegiatan yang dilakukan secara berdaya guna dan berhasil guna, dalam memperoleh hasil yang lebih, (Kamus Besar Bahasa Indonesia, 1990:117). Selanjutnya, Dirjen Dikdasmen (2004:16) menjelaskan bahwa kinerja yang efektif dapat merangsang kreativitas guru untuk memunculkan gagasan, perubahan dan pembaharuan yang pada akhirnya bertujuan untuk memperbaiki dan mengembangkan proses pembelajaran yang baik.

Menurut Locke and Latham (dalam Supardi, 2013: 48) secara individual, kinerja seseorang ditentukan oleh beberapa bidang sebagai berikut: (a) kemampuan, (b) komitmen, (c) umpan balik, (d) kompleksitas tugas, (e) kondisi yang menghambat, (f) tantangan, (g) tujuan, (h) fasilitas, keakuratan dirinya, (i) arah usaha, (j) daya tahan/ketekunan, (k) strategi khusus dalam menghadapi tugas. Di samping itu, perlu adanya kerjasama yang baik antara Guru BK dengan personil sekolah dalam menunjang pelayanan BK di sekolah. Pengetahuan dan keterampilan dalam pelaksanaan pelayanan BK menjadi faktor utama Guru BK sebagai pelaksana tugas, sesuai dengan aturan pemerintah berdasarkan Permendikbud No.111 Tahun 2014 tentang Bimbingan dan Koseling pada Pendidikan Dasar dan Menengah. 
Berdasarkan penjelasan di atas dapat disimpulkan bahwa, kualitas kinerja Guru BK secara keseluruhan berkenaan dengan usaha atau kegiatan yang dilakukan oleh Guru BK dalam pelaksanaan pelayanan BK masih perlu ditingkatkan, dengan cara memberikan kesempatan kepada Guru BK agar diberikan jam masuk kelas untuk menyelenggarakan kegiatan BK, dan mengikuti kegiatan pelatihan, seminar, lokakarya BK serta kegiatan MGBK, agar Guru BK mengetahui perkembangan yang ada dari ilmu pendidikan bimbingan dan konseling itu sendiri. Hal ini bertujuan untuk memperbaiki kondisi kinerja Guru BK terhadap tugas dan tanggung jawabnya dalam melaksanakan pelayanan BK di sekolah, agar menjadi lebih profesional.

\section{Pembinaan Kinerja Guru BK oleh Kepala Sekolah}

Berdasarkan analisis deskripsi data yang diperoleh, menunjukkan bahwa pembinaan kinerja Guru BK yang dilakukan oleh Kepala Sekolah secara umum berada pada kategori sangat kurang. Jika dianalisis berdasarkan skor item instrumen, pembinaan kinerja Guru BK oleh Kepala Sekolah per- jenjang sekolah menunjukkan bahwa untuk jenjang SMP/MTs berada pada kategori kualitas sangat kurang dan tidak satupun dari item pernyataan tersebut berada pada kualitas kurang, cukup, baik dan baik sekali. Hal ini berarti, apa yang dilakukan oleh Kepala Sekolah dalam melakukan pembinaan terhadap Guru BK belum terlaksana dengan baik.

Pada jenjang SMA/SMK/MA, pembinaan kineja Guru BK oleh Kepala Sekolah sudah mulai terlaksana, namun masih belum menyeluruh. Seperti yang terlihat pada tabel 15 bahwa kualitas pembinaan kinerja Guru BK oleh Kepala Sekolah berada pada kategori cukup, hanya untuk pembagian siswa asuh saja. Selanjutnya, berkenaan dengan pelayanan BK khususnya pada sarana, prasarana dan pembiayaan dalam menunjang pelaksanaan pelayanan BK berada pada kategori kurang dan sangat kurang. Artinya, pembinaan kinerja Guru BK yang dilakukan oleh Kepala Sekolah baik itu pada jenjang SMP/MTs maupun pada jenjang SMA/SMK/MA belum sepenuhnya terlaksana secara maksimal. Untuk itu perlu adanya upaya yang dilakukan oleh Kepala Sekolah secara keseluruhan agar Guru BK dapat meningkatkan kualitas kinerjanya, dalam hal ini melalui bantuan dan peran Kepala Sekolah sebagai pembina dengan memberikan kesempatan, Kepada Guru BK untuk bisa melaksanakan pelayanan BK sesuai dengan ketentuan resmi dari pemerintah, berdasarkan Permendikbud No.111 Tahun 2014 tentang Bimbingan dan Konseling untuk Tingkat Dasar dan Menengah. 
Senada dengan penelitian Siraj (2013) menjelaskan bahwa, hasil penelitian peningkatan sumber daya Guru BK dilaksanakan melalui bantuan Kepala Sekolah dalam bentuk observasi kelas, pembicaraan individual, dan rapat guru. Adapun hambatan- hambatan yang muncul dalam upaya meningkatkan kinerja Guru BK yang seperti sarana dan prasarana yang terbatas, kurang disiplinnya Guru BK, serta masih kurangnya pengetahuan Guru BK tentang pengelolaan proses belajar mengajar dan pemberian konseling yang efektif. Pembinaan kinerja yang dilakukan oleh Kepala Sekolah bertujuan memberikan layanan dan bantuan dalam meningkatkan kualitas kinerja pada setiap guru seperti Guru Mata Pelajaran, wali kelas, Guru BK atau Konselor guna meningkatkan kualitas dan efektivitas dalam pekerjaannya, sesuai dengan bidangnya masing-masing (Sahertian, 2000:19). Pada bidang bimbingan dan konseling diharapkan Kepala Sekolah turut serta berperan aktif dalam memfasilitasi kebutuhan konseling seperti pengadaan sarana, prasarana dan pembiayaan dalam menunjang pelaksanaan pelayanan $\mathrm{BK}$, berdasarkan dengan ketentuan yang ada, agar penyelenggaraan pelayanan BK yang efektif dan efisien tercapai, seperti ruang BK yang merupakan ruang kerja dari Guru BK. Hal ini sangat diperlukan serta memiliki kontribusi terhadap keberhasilan proses layanan bimbingan dan konseling di satuan pendidikan.

Selanjutnya Permendikbud Nomor 81 A Tahun 2013 menjelaskan, bahwa Guru BK atau Konselor wajib melakasanakan kegiatan tatap muka di dalam kelas. Ini dilaksanakan secara klasikal dengan rombongan belajar siswa dalam tiap kelas untuk menyelenggarakan pelayanan BK seperti memberikan layanan informasi, penempatan dan penyaluran, penguasaan konten, kegiatan instrumentasi, serta layanan/ kegiatan lain yang dapat dilakukan di dalam kelas serta pembagian siswa asuh dengan rasio 1:150. Artinya satu orang Guru BK melakukan pembinaan dan bimbingan kepada 150 siswa.

Berdasarkan penjelasan di atas dapat disimpulkan bahwa pembinaan kinerja Guru BK yang dilakukan oleh Kepala Sekolah di Kabupaten Merangin secara keseluruhan berada pada kategori cukup. Hal ini menjadi sangat penting untuk segera dilakukan, pembenahan dalam upaya melakukan pembinaan kinerja Guru BK oleh Kepala Sekolah agar lebih profesional, bermandat dan bermanfaat bagi peserta didik di sekolah terhadap keberadaan Guru BK. Data penelitian ini dapat dijadikan sebagai bahan pertimbangan kepada Kepala Sekolah dalam mendukung program BK yang telah direncanakan dan disusun oleh Guru BK terhadap pelaksanaan pelayanan BK, serta memenuhi kebutuhan yang diperlukan oleh Guru BK seperti memberikan kesempatan dan fasilitas kepada Guru BK, untuk melakukan 
penyelenggaraan pelayanan BK di dalam kelas, agar tercapainya pelaksanaan pelayanan BK yang berhasil.

\section{Pembinaan Kinerja oleh Pengawas BK}

Berdasarkan analisis deskripsi data yang diperoleh, menunjukkan bahwa pembinaan kinerja Guru BK yang dilakukan oleh Pengawas BK secara umum berada pada kategori sangat kurang. Jika dianalisis berdasarkan skor item instrumen, pembinaan kinerja Guru BK oleh Pengawas BK per- jenjang sekolah menunjukkan bahwa untuk jenjang SMP/MTs berada pada kategori kualitas sangat kurang dan tidak satupun dari item pernyataan tersebut berada pada kualitas kurang, cukup, baik dan baik sekali. Hal ini berarti, apa yang dilakukan oleh Pengawas BK dalam melakukan pembinaan terhadap Guru BK belum terlaksana dengan baik.

Pada jenjang SMA/SMK/MA, pembinaan kineja Guru BK oleh Kepala Sekolah sudah mulai terlaksana, namun masih belum menyeluruh. Seperti yang terlihat pada tabel 20 bahwa kualitas pembinaan kinerja Guru BK oleh Pengawas BK berada pada kategori kurang dan sangat kurang. Artinya, pembinaan kinerja Guru BK yang dilakukan oleh Pengawas BK baik itu pada jenjang SMP/MTs maupun pada jenjang SMA/SMK/MA belum sepenuhnya berjalan. Data ini didukung juga dari hasil wawancara yang peneliti lakukan kepada 2 Pengawas BK pada jenjang SMP/MTs dan SMA/SMK/MA pada tanggal 12 Januari 2016 di ruang pola Dinas Pendidikan Kabupaten Merangin. Berdasarkan wawancara yang peneliti lakukan bahwa secara umum pembinaan kinerja yang dilakukan oleh Pengawas BK terhadap Guru BK se- Kabupaten Merangin, belum dilakukan secara menyeluruh, hanya sekolah yang berada di dalam kota Merangin saja. Senada dengan Tri Anjar (2012) menjelaskan bahwa, hasil penelitian terhadap proses pembinaan dan pengawasan yang benar, oleh Pengawas BK kepada Guru BK berkaitan erat terhadap kompetensi profesional. Hal ini sangat dibutuhkan untuk menunjang kualitas pelayanan konseling yang dilakukan oleh Guru BK seperti kegiatan supervisor, educator, dan motivator.

Pola pengawasan yang terstruktur, jujur, dan berdasarkan analisis masalah pelayanan BK di sekolah, akan mampu memberikan kontribusi yang baik dalam rangka perbaikan, evaluasi, dan peningkatan pelayanan BK, serta profesionalitas Guru BK sebagai penyelenggara layanan. Hal yang terjadi, ternyata masih ditemukan Pengawas BK yang melakukan pembinaan kinerja Guru BK hanya sebatas pengecekan administrasi BK, dan belum sampai pada tahap bagaimana pelaksanaan pelayanan BK dilaksanakan di 
sekolah. Di samping itu, Depdiknas (2009) menyebutkan pelaksanaan, pembinaan, dan penilaian Pengawas BK terhadap Guru BK yaitu.

a. Kegiatan supervisi BK meliputi pembinaan dan pematauan pelaksanaan BK di sekolah merupakan kegiatan dimana terjadi interaksi langsung antara pengawas dengan guru binaannya.

b. Melaksanakan penilaian berupa menilai kinerja Guru BK dalam merencanakan melaksanakan dan menilai proses bimbingan.

c. Kegiatan ini dilakukan di sekolah binaan, sesuai dengan uraian kegiatan dan jadwal yang tercantum dalam RKBK yang telah disusun.

Berdasarkan perbandingan data di atas dapat disimpulkan bahwa pembinaan kinerja yang dilakukan oleh Pengawas BK secara menyeluruh berada pada kategori cukup. Hal ini perlu mendapat perhatian dalam upaya meningkatkan pembinaan kinerja Guru BK. Kunjungan yang dilakukan oleh Pengawas BK, dapat dijadikan sebagai motivasi bagi Guru BK, dalam meningkatkan kualitas kinerja Guru BK di sekolah. Adapun bentuk tanggung jawab Pengawas BK terhadap kunjungan yang dilakukan oleh Pengawas BK seperti melaksanakan tugas pokok dan tanggung jawabnya diatur dalam ekuivalensi kegiatan kerja Pengawas BK yaitu 24 jam tatap muka dalam 1 minggu, menggunakan pendekatan jumlah guru yang dibina, pada satu atau beberapa sekolah untuk jenjang pendidikan yang sama atau jenjang pendidikan yang berbeda. Jumlah guru yang harus dibina untuk Pengawas BK paling sedikit 40 dan paling banyak 60 Guru BK (Depdiknas, 2009: 39). Data penelitian ini dapat dijadikan sebagai bahan masukan dan pertimbangan bagi Pengawas BK dalam melakukan pembinaan kinerja Guru BK di sekolah, mengingat pentingnya dukungan dan bantuan dari Pengawas BK kepada Guru BK untuk bisa melaksanakan pelayanan BK yang berhasil di sekolah.

\section{KESIMPULAN}

Berdasarkan temuan dan pembahasan hasil penelitian, maka dapat dikemukakan kesimpulan tentang:

1. Kualitas kinerja Guru BK dalam responden penelitian ini terhadap pelaksanaan pelayanan BK di sekolah secara umum masih harus diperbaiki baik untuk pelaksanaan maupun pengetahuan Guru BKnya. Pada hasil penelitian ini menunjukkan bahwa kualitas pelaksanaan kinerja Guru BK berada pada kategori kurang, dengan persentase sebesar 55,09\%. Jika dilihat pada setiap item instrumen, kualitas kinerja Guru BK terhadap aspek- aspek pelaksanaan pelayanan BK, berada pada kategori kualitas sangat 
kurang dengan capaian sebesar 33\%, dan kategori kurang dengan capaian sebesar 67\%.. Artinya kualitas pelaksanaan kinerja Guru BK terhadap pelayanan BK secara keseluruhan belum terlaksana dengan baik sesuai dengan kompetensi profesional Guru BK.

2. Pembinaan kinerja Guru BK yang dilakukan oleh Kepala Sekolah secara umum perlu diperbaiki dan ditingkatkan, baik dari segi pelaksanaan dan bentuk pembinaan yang dilakukan, karena hasil penelitian menunjukkan bahwa pembinaan kinerja Guru BK yang dilakukan oleh Kepala Sekolah berada pada kategori sangat kurang dengan persentase sebesar 52,9\%. Selanjutnya, jika dilihat berdasarkan kualitas pelaksanaan setiap item instrumen tersebut, berada pada kategori sangat kurang dengan capaian $55 \%$, dan kategori kurang, dengan capaian $44 \%$ serta hanya satu item yang mencapai kategori cukup yaitu item nomer 55 tentang pembagian siswa asuh sebesar 1\%. Artinya kegiatan pembinaan kinerja Guru BK yang dilakukan oleh Kepala Sekolah per- jenjang sekolah, telah terlaksana. Namun belum secara menyeluruh terlaksana, khususnya terhadap pengadaan fasilitas sarana, prasarana dan pembiayaan dalam menunjang pelaksanaan pelayanan BK di sekolah. Hal ini merupakan salah satu masalah yang dihadapi Guru BK dalam melakukan pelayanan BK di sekolah.

3. Pembinaan kinerja yang dilakukan oleh Pengawas BK terhadap pelaksanaan pelayanan BK di sekolah masih perlu untuk diperbaiki dan ditingkatkan baik dari segi pelaksanaan maupun pengecekan administrasi BK secara menyeluruh, karena hasil penelitian menunjukkan bahwa pembinaan kinerja Guru BK yang dilakukan oleh Kepala Sekolah berada pada kategori sangat kurang dengan capaian sebesar 51,87\%. Selanjutnya, jika dilihat berdasarkan setiap item instrumen, pembinaan kinerja Guru BK yang dilakukan hanya berada pada kategori sangat kurang, dengan capaian 54\% dan untuk kategori kurang, mencapai 46\%. Artinya pembinaan kinerja Guru BK yang dilakukan oleh Pengawas BK baik jenjang SMP/MTs dan SMA/SMK/MA masih belum optimal dan menyeluruh. Data ini di dukung juga dari wawancara yang dilakukan oleh peneliti kepada Pengawas BK bahwa pembinaan yang dilakukan Pengawas BK kepada Guru BK di Kabupaten Merangin, baru pada tahap pengecekan adminisrasi BK saja dan masih belum secara menyeluruh dilakukannya. 


\section{SARAN}

Hasil data penelitian, pembahasan dan kesimpulan yang telah diuraikan sebelumnya bahwa kualitas kinerja Guru BK dan pembinaan yang dilakukan oleh Kepala Sekolah serta Pengawas BK perlu untuk diperbaiki dan ditingkatkan pelaksanaannya. Berkaitan dengan hal tersebut, terdapat beberapa saran yaitu kepada:

1. Guru BK hendaknya dalam pembuatan program BK di sekolah, agar merencanakan dan menyusunnya berdasarkan need assesment, sehingga Guru BK mengetahui kebutuhan siswa dalam memperoleh layanan BK. Selanjutnya, Guru BK dituntut mengembangkan pengetahuan dan kemampuannya dalam menjalankan tugas serta tanggung jawabnya sebagai seorang guru yang profesional melalui kegiatan pelatihan, seminar, lokakarya BK, dan kegiatan MGBK di Kabupaten Merangin, dengan tujuan meningkatkan ilmu pengetahuan dan pemahaman Guru BK terhadap kompetensi profesioanal Guru BK, sehingga pelaksanaan pelayanan BK dapat dirasakan manfaatnya oleh siswa.

2. Kepala Sekolah hendaknya agar dapat memberikan kesempatan kepada Guru BK dalam melaksanakan pelayanan BK di sekolah sesuai dengan ketentuan dari pemerintah melalui Permendikbud No.111 Tahun 2014 tentang Bimbingan dan Konseling Pada Tingkat Pendidikan Dasar dan Menengah diantaranya, melakukan kegiatan tatap muka di dalam kelas selam 2 jam pembelajaran perminggu setiap kelas, menentukan siswa asuh dengan rasio 1:150, menyediakan sarana, prasarana dan pembiayaan dalam menunjang pelayanan BK di sekolah. Hal ini penting untuk dilakukan, karena akan mempengaruhi terhadap pelaksanaan pelayanan BK yang dilakukan oleh Guru BK di sekolah.

3. Pengawas BK hendaknya agar memberikan pembinaan kinerja secara merata dan menyeluruh kepada Guru BK binaanya. Hal ini penting dilakukan, agar Guru BK termotivasi untuk melakukan pembenahan dan meningkatkan kemampuannya dalam melakukan pelayanan BK di sekolah. Hadirnya Pengawas BK di sekolah tentu akan berdampak pada kinerja Guru BK dalam melakukan pelayanan BK serta memahami kendala apa saja yang dihadapi oleh Guru BK di sekolah.

4. Dinas Pendidikan Kabupaten Merangin, agar memberikan dukungan secara moril dan materil terhadap pengembangan profesi Guru BK melalui kegiatan MGBK. Hal ini penting dilakukan mengingat, peran Dinas Pendidikan Kabupaten Merangin sebagai Institusi Pendidikan, agar Guru BK dapat menjalankan pelayanan BK di sekolah, 
sesuai dengan ketentuan pemerintah melalui Permendikbud No.111 Tahun 2014 tentang Bimbingan dan Konseling Pada Tingkat Pendidikan Dasar dan Menengah. 


\section{DAFTAR RUJUKAN}

Arikunto, Suharsimi. 2010. Manajemen Penelitian. Jakarta : Rineka Cipta.

Asmaryadi. 2013. Kinerja Guru Bimbingan dan Konseling dalam Pelayanan Bimbingan dan Konseling dan Upaya Pembinaan yang dilakukan Kepala sekolah. Tesis tidak diterbitka. Padang: Program Pascasarjana UNP.

Depdiknas. 2009. Pedoman Pelaksanaan Tugas Guru dan Pengawas. Jakarta: Direktorat Jendral Peningkatan Mutu dan Tenaga Kependidikan.

Irianto, Agus. 2010. Statistik Konsep: Dasar, aplikasi, dan pengembangannya. Jakarta: Kencana.

Ozkan, Metin. 2014. Measurent Of Relaive Perfomance Of Guidance and Psycological Counseling Undergraduate Program in Turkey. Journal. Turkey: University Faculty Of Education Depertement Of Education Educaion Sciences.

Permendikbud. Nomor 81 A Tahun 2013. tentang Implementasi Kurikulum

Permendikbud Nomor 111 Tahun 2014 tentang Bimbingan dan Konseling Pada Pendidikan Dasar dan Menengah. Jakarta: Kementerian Pendidikan Nasional.

Prayitno. 2001. Panduan Kegiatan Pengawas Bimbingan dan Konseling di Sekolah. Jakarta: Asdimahasatya.

Prayitno. 2004. Pedoman Khusus Bimbingan dan Konseling, Jakarta: Depdiknas.

Purwanto, N. 2008. Metodologi Penelitian Kuantitatif untuk Psikologi dan Pendidikan. Yogyakarta: Pustaka Belajar.

Sahertian, P.A. 2000. Konsep Dasar dan Tehnik Supervisi Pendidikan dalam Rangka Pengembangan Sumber Daya Manusia. Jakarta: Rineka Cipta.

Siraj. 2013. Peningkatan Kinerja Konselor Melalui Peran Supervisi Pendidikan Pada SMA N 1 Makmur Kabupaten Bireuen. Jurnal Tesis. Medan: UNIMED

Sunoko. 2011. Pembinaan Profesional Guru ( Studi Kasus Pembinaan oleh Kepala Sekolah, Pengawas, dan Dinas Pendidikan di SMPN 2 Sarolangun). Disertasi Tidak diterbitkan. Program Pascasarjana UNP.

Supardi. 2013. Kinerja Guru. Jakarta: Raja Grafindo Persada.

Undang-Undang RI No. 20 Tahun 2003 tentang Guru dan Dosen.

Zukhufarisma. 2012. Implementasi Supervisi Pendidikan oleh Kepala Sekolah terhadap Guru. Artikel. (Online), Vol. 9, No. 2, (http://digilib.Unimed.ac.id diakses 4 Februari 2015). 